\title{
Agro-morphological Variability of Bottle Gourd Accessions Lagenaria siceraria (Molina) Standl in Côte d'Ivoire
}

\author{
YAO Kouakou Abessika Georges ${ }^{1}$, BONNY Becket Sévérin ${ }^{2}$, GORE Bi Boh Nestor ${ }^{1}$, KOFFI Kouamé \\ Kevin' $^{2}$, AKAFFOU Doffou Sélastique ${ }^{1}$ and ZORO Bi Irié Arsène ${ }^{2}$ \\ ${ }^{1}$ Department of Agronomy and forestry, of Jean Lorougnon Guede University, BP 150 Daloa \\ ${ }^{2}$ Department of Nature Sciences, of Nangui Abrogoua University, 02 BP 801 Abidjan 02
}

Côte d'Ivoire

\begin{abstract}
Bottle gourd Lagenaria siceraria (Molina) Standl is one of oleaginous cucurbits grown in Côte d'Ivoire with socio-economic and food importance that could play an important role in food security. The increase in the production of this species for improvement of plant yield remains a major challenge that begins with the agro-morphological characterization of local varieties present in different production areas. The objective of this study is to estimate agro-morphological variability within Lagenaria siceraria seed collection of Nangui Abrogoua University. The study focused on 26 accessions collected in the different production areas of the species. The experimental design is a randomized complementary block. Descriptive analyzes under the observation of fourteen descriptors showed existence of a great variability between accessions for the yield characters. Multiple variance analysis showed that there is a highly significant difference between accessions and provenances for the majority of traits studied. The structuring of accessions according to areas collection revealed by principal component analysis is confirmed by discriminant factor analysis. The classification of accessions and identification of the groups were carried out by hierarchical ascending classification which made it possible to elaborate a dendrogram which presents two groups of phenotypic diversity. It appears that the most relevant variables that describe the best variability between groups are fruit size $(F H)$, fruit weight $(F W)$, number of seed (NS), and seed weight (SW). These analyzed characters can thus constitute basic criteria to differentiate accessions and to be used in studies of morphological diversity of $L$. siceraria.
\end{abstract}

Key Words: Lagenaria siceraria, Oleaginous cucurbits, Morphological variability, Accessions, Dendogram.

\section{INTRODUCTION}

Valorization of traditional varieties only helps to enrich genetic diversity, promote the internal market and exports, but also contributes significantly to the food security of millions of people who make their livelihoods from agriculture [1]. Today, Southern governments and development agencies are promoting the production of traditional cultures, given the crucial role they can play in the stability of incomes and the livelihoods of the people who produce them. [2].Therefore, in most African countries, genetic resources are not yet fully exploited in agriculture. Among these, Cucurbitaceae family contains several species known as Egussi in some West African countries such as Nigeria [3], Benin, Togo, and Ghana [4]. In Côte d'Ivoire, five species of oil crops known under the generic name of Pistachio have been identified. On these species, Lagenaria siceraria (Molina) Standl.is the most cultivated in production areas [5]. shelled seeds of $L$. siceraria are traded extensively in rural and urban markets, as are some highly cultivated food crops such as groundnuts (Arachis hypogaea L.), maize (Zea mays L.), and voandzou (Vigna subterranea (L.) Verdc.). The seeds of $L$. siceraria are rich in lipids and proteins [6,7]. They constitute today a complementary source of income for women producers [8]. Despite the great socioeconomic importance, oleaginous cucurbit crops, know a decrease in production. Their cultivation encounters enormous difficulties generally in tropical zones, and particularly in Côte d'Ivoire [9], which significantly affects yield. One of the sure ways to guarantee the additional resources of producers who are generally women and to encourage them to continue the practice of cultivation is thus to increase the productivity of plant. To achieve this, one of the steps to be taken is to evaluate the agro-morphological characteristics of the varieties present in the different production 
zones. Indeed, evaluation of the genetic diversity of a species is a prerequisite for any varietal breeding program for this species [10]. The allogamous reproduction regime that characterizes Cucurbitaceae generates a great genetic variability within this family. Indeed, studies on morphological characterization have been carried out with calabash-type varieties of L. siceraria [11, 12].These studies using quantitative traits have shown that a large variability exists within the species [13, 14, 15]. In addition, molecular diversity studies conducted in Kenya using the Random Amplified Polymorphic DNA (RAPD) technique have shown that $L$. siceraria and three wild species of the genus Lagenaria (L. sphaerica, L. abyssinica, and L. breviflora) were different from each other [16]. In addition, another study using the same marker distinguished L. siceraria from L. sphaerica [17]. Morphological and agronomic characterization studies indicate the existence of different varieties within L. siceraria oleaginous type [18]. On the other hand, a study carried out in Côte d'Ivoire on the morphological and enzymatic variability of L. siceraria showed a similarity in the cultivars studied, despite the fact that these cultivars come from different geographical areas. According to [12], this could be explained by a weak discriminating power of the markers used to identify the genetic bases of the agro-morphological variation within the species. These different studies have shown the existence of diversity within the oleaginous type of $L$. siceraria. These results suggest that the genetic resources of the oleaginous form of $L$. siceraria can be used as part of the varietal improvement of this plant. The main objective of this study is the estimation of agro-morphological variability of accessions of the oleaginous form L. siceraria within the collection of the University Nangui Abrogoua in order to appreciate its potential in terms of material work for the breeders of this plant.

\section{MATERIAL AND METHOD}

\subsection{Plant Material}

The accessions collection of this study consisted of 26 accessions, of which twelve (12) come from the collection carried out in the south of Côte d'Ivoire (Alepe); nine (9) from the East (Bondoukou) and five (5) from the Center (Bouafle). Five (5) plants were evaluated per accession, making a total of 130 plants. These accessions are coded according to their origin in the Table 1 . The geographical coordinates and ecological traits of sites of the collecting missions are as follows [9]:

- The southern zone is localized between latitudes $4^{\circ} 41 \mathrm{~N}-6^{\circ} 00 \mathrm{~N}$ and longitudes $4^{\circ} 00 \mathrm{~W}-7^{\circ} 30 \mathrm{~W}$. Rainfalls are abundant (annual mean $>2,000 \mathrm{~mm}$ ) and mean annual temperature is $28^{\circ} \mathrm{C}$, with annual amplitude of $5-10^{\circ} \mathrm{C}$. Vegetation is mainly represented by the tropical rain forest, with mangrove on the coastal side.

- The eastern zone is limited by latitudes $6^{\circ} 00 \mathrm{~N}-8^{\circ} 00 \mathrm{~N}$ and longitudes $3^{\circ} 00 \mathrm{~W}-5^{\circ} 00 \mathrm{~W}$. In this area is characterized by the transitional woodland savannas, with several blocks of semi-deciduous forests. Rainfalls vary from 875 to $1,910 \mathrm{~mm}$, with an annual mean of $1,250 \mathrm{~mm}$; the annual mean temperature is $27^{\circ} \mathrm{C}$.

- The central zone is limited by latitudes $6^{\circ} 00 \mathrm{~N}-8^{\circ} 00 \mathrm{~N}$ and longitudes $5^{\circ} 00 \mathrm{~W}-7^{\circ} 00 \mathrm{~W}$. Annual rainfalls vary from 800 to 1,400 $\mathrm{mm}$, with an annual mean of $1,200 \mathrm{~mm}$; the annual mean temperature is $27^{\circ} \mathrm{C}$. The vegetations are made of various woodland savannas with extended ranges of herbaceous areas. 
International Journal of Advances in Scientific Research and Engineering (ijasre), Vol 5 (7), July-2019

Table 1. List and Origin of 26 Accessions of $L$. siceraria

\begin{tabular}{cccccccccccc}
\hline \hline $\mathbf{N}^{\circ}$ & Identification & Origin & Code & $\mathbf{N}^{\circ}$ & Identification & Origin & Code & $\mathbf{N}^{\circ}$ & Identification & Origin & Code \\
\hline $\mathbf{1}$ & NI199 & South (Alepe) & S199 & $\mathbf{1 0}$ & NI249 & South (Alepe) & S249 & $\mathbf{1 9}$ & NI329 & East (Bondoukou) & E329 \\
$\mathbf{2}$ & NI202 & South (Alepe) & S202 & $\mathbf{1 1}$ & NI252 & South (Alepe) & S252 & $\mathbf{2 0}$ & NI341 & East (Bondoukou) & E341 \\
$\mathbf{3}$ & NI215 & South (Alepe) & S215 & $\mathbf{1 2}$ & NI260 & South (Alepe) & S260 & $\mathbf{2 1}$ & NI354 & East (Bondoukou) & E354 \\
$\mathbf{4}$ & NI219 & South (Alepe) & S219 & $\mathbf{1 3}$ & NI274 & East (Bondoukou) & E274 & $\mathbf{2 2}$ & NI91 & Center (Bouafle) & C91 \\
$\mathbf{5}$ & NI224 & South (Alepe) & S224 & $\mathbf{1 4}$ & NI276 & East (Bondoukou) & E276 & $\mathbf{2 3}$ & NI106 & Center (Bouafle) & C106 \\
$\mathbf{6}$ & NI227 & South (Alepe) & S227 & $\mathbf{1 5}$ & NI283 & East (Bondoukou) & E283 & $\mathbf{2 4}$ & NI109 & Center (Bouafle) & C109 \\
$\mathbf{7}$ & NI228 & South (Alepe) & S228 & $\mathbf{1 6}$ & NI304 & East (Bondoukou) & E304 & $\mathbf{2 5}$ & NI160 & Center (Bouafle) & C160 \\
$\mathbf{8}$ & NI240 & South (Alepe) & S240 & $\mathbf{1 7}$ & NI305 & East (Bondoukou) & E305 & $\mathbf{2 6}$ & NI174 & Center (Bouafle) & C174 \\
$\mathbf{9}$ & NI247 & South (Alepe) & S247 & $\mathbf{1 8}$ & NI328 & East (Bondoukou) & E328 & & & & \\
\hline
\end{tabular}

NI: Identification Numbers; S: South; E: East; C: Center, 
International Journal of Advances in Scientific Research and Engineering (ijasre), Vol 5 (7), July-2019

\subsection{Methods}

\subsubsection{Experimental Design and Cultural Practice}

The experiment was conducted in the district of Abidjan (Côte d'Ivoire). The experimental site was located in Abidjan suburb, between latitudes $5^{\circ} 17^{\prime} \mathrm{N}-5^{\circ} 31^{\prime} \mathrm{N}$ and longitudes $3^{\circ} 45^{\prime} \mathrm{W}-4^{\circ} 22^{\prime} \mathrm{W}$. In this zone, rainfalls are abundant (annual mean > 2,000 mm) and the mean temperature is $28^{\circ} \mathrm{C}$, with annual amplitude of $5-10^{\circ} \mathrm{C}$. The experimental design is a completely randomized block, established on a plot of $768 \mathrm{~m} 2$, ie $64 \mathrm{~m} \times 12 \mathrm{~m}$. Three seeds were sown in a same day on the whole plot. The seedlings are demilled after emergence so as to keep only the most vigorous. The distance between the sowing points is $3 \mathrm{~m}$. This distance makes it possible to take into account the creeping nature of the species that covers the ground very quickly. The test is carried out in pure culture without fertilization. Three insecticides treatment with cypercal $50 \mathrm{EC}$ (carbamate) are used to reduce insects impacts. The first occurred as soon as $50 \%$ of the plants began to crawl. The second, at the beginning of the male flowering and finally, the third on time of first fruits formation. Regular weeding is done to avoid any competition between weeds and plants of interest.

\subsubsection{Parameters Evaluated}

Data collection was done throughout the plant's development cycle. The parameters evaluated concern vegetative development, fruits and seeds. In this study measurement of the traits followed the methods used by [14] and [28].These traits are as follows: number of days from sowing to emergence (TE); number of branches (NB); first fruit maturity (FM); number of fruits per plant (NF); fruit weight (FW); seeds lodge cavity diameter (CD); fruit diameter (FD); fruit height (FH); plant length (PL); number of seeds per fruit (NS); seed weight per fruit (SW); 100-seedweight (100-SW); sex ratio (SR); harvest index (HI).

\subsection{Statistical Analyzes of Data.}

The measured parameters were the subject of a descriptive analysis. The mean and dispersion parameters of the standard deviation, the range (maximum, minimum) and the coefficient of variation (CV) have been calculated. In addition, multivariate analysis of variance (MANOVA) was used to compare biological material according to two criteria (accessions and collection area). The assessment of morphological diversity structuring was performed by principal component analysis (PCA). The hierarchical ascending classification (HAC) was used in this study to highlight and classify homogeneous groups among the accessions. Discriminant factor analysis (DFA) is a third method of multivariate analysis that complements the principal component analysis. These analyzes were done using Statistica software version 7.1 [19].

\section{Results}

\subsection{Variability of Morphological Characters}

The mean, standard deviation, minimum, maximum and coefficient of variation are summarized in Table 2. Significant variations were observed between the extreme values (minimum and maximum) and the coefficients of variation. Amplitudes are very high, especially in the parameters of vigor and efficiency. The coefficients of variation observed vary from 7.28 (emergence time) to $81.08 \%$ (number of fruits).A rate of about $71 \%$ of the characters have a coefficient of variation greater than $25 \%$. These characters are essentially those relating to vigor, yield, and vegetative aspect. Phenological characters have low coefficients of variation. All vegetative parameters have important coefficients of variation, ie greater than $25 \%$. But, the best amplitude was observed with the length of the plant stem. In terms of vigor and yield parameters, the best amplitudes were respectively observed on fruit weight, 100 -seed weight and number of seeds. 
International Journal of Advances in Scientific Research and Engineering (ijasre), Vol 5 (7), July-2019

Table 2. Mean, standard deviation, minimum, maximum and Coefficient of Variation (CV) of 14 quantitative characters Measured on 26 accessions of Lagenaria siceraria

\begin{tabular}{ccccc}
\hline \hline Characters & Mean & Minimum & Maximum & CV (\%) \\
\hline TE (d) & $5.17 \pm 0.38$ & 5 & 6 & 7.28 \\
FM (d) & $113.77 \pm 10.84$ & 102 & 127 & 9.51 \\
SR & $0.10 \pm 0.06$ & 0.01 & 0.25 & 54.82 \\
NB & $1.42 \pm 0.5$ & 1 & 2 & 34.98 \\
LP (m) & $7.89 \pm 3.93$ & 1.40 & 21.60 & 49.81 \\
NF & $3.58 \pm 2.91$ & 1 & 15 & 81.08 \\
FW (g) & $980.58 \pm 498.06$ & 350 & 2800 & 50.79 \\
FH (cm) & $14.28 \pm 4.28$ & 8.70 & 38.8 & 29.98 \\
FD (cm) & $12.20 \pm 2.22$ & 9 & 26.6 & 18.18 \\
CD (cm) & $8.52 \pm 1.80$ & 6 & 19.8 & 21.15 \\
NS & $249.89 \pm 85.68$ & 91 & 371 & 34.29 \\
100-SW (g) & $16.29 \pm 5.58$ & 8.68 & 46.44 & 34.27 \\
HI & $0.04 \pm 0.01$ & 0.01 & 0.07 & 27 \\
SW (g) & $41.19 \pm 23.32$ & 8.00 & 100.75 & 56.61 \\
\hline \hline
\end{tabular}

TE: Emergence time; FM: First fruit maturity; NB: Number of branches; PL: Plant length; SR: Sex ratio; NS: Number of fruits;

FW: Fruit weight. FH: Fruit height; FD: Fruit diameter; CD: Diameter of cavity lodge of seed; NS: Number of seeds per fruit; 100-SW: 100-seedWeight; HI: Harvest index; SW: Seed weight per plant

\subsection{Analysis of Agro-morphological Variability According to Accessions}

The Multiple Analyses of variance results comparing accessions indicate a very highly significant difference $(F=2,239, P$ $<0,001)$. Univariate analyzes of the variables show that 13 of them contribute to the difference between accessions. The largest values of TE, NB, PL, FM, NF, FH, FD, CD, NS, 100-SW, HI, SR and SY were obtained with the NI341, NI354, NI252, NI283, NI228, NI106, NI304 and respectively (Table 3). On the other hand, the lowest values are observed respectively with accessions NI215, NI354, NI174, NI219, NI202, NI224 and NI249.

With the exception of TE, FM and SY, the extreme values of the parameters vary at least from single to double. NI283 expressed the largest values of six parameters, followed by NI354, which expressed three parameters. The maximum of low values was observed in accessions NI174 and NI215, each of which had four parameters.

Table 3. ANOVA results comparing 26 accessions of Lagenaria siceraria

\begin{tabular}{|c|c|c|c|c|c|c|c|}
\hline \multirow[b]{2}{*}{ Characters } & \multirow[b]{2}{*}{$\boldsymbol{F}$} & \multirow[b]{2}{*}{$\boldsymbol{P}$} & \multicolumn{2}{|c|}{ Maximum } & \multicolumn{2}{|c|}{ Minimum } & \multirow{2}{*}{ Means } \\
\hline & & & Accessions & Values & Accessions & Values & \\
\hline TE (d) & 13.369 & $<0.001$ & NI341 & 5.50 & $\mathrm{NI} 215$ & 5.00 & $5.17 \pm 0.38$ \\
\hline FM (d) & - & - & $\mathrm{NI} 283$ & 127 & $\mathrm{NI} 215$ & 102 & $113.77 \pm 10.84$ \\
\hline SR & 2.248 & 0.004 & NI354 & 0.16 & NI174 & 0.034 & $0.10 \pm 0.06$ \\
\hline NB & 5.201 & $<0.001$ & $\mathrm{NI} 252$ & 2.00 & NI354 & 1.00 & $1.42 \pm 0.5$ \\
\hline PL (m) & 1.773 & 0.031 & $\mathrm{NI} 283$ & 14.67 & $\mathrm{NI} 215$ & 3.10 & $7.89 \pm 3.93$ \\
\hline $\mathbf{N F}$ & 1.897 & 0.018 & NI228 & 6.5 & NI174 & 1.00 & $3.58 \pm 2.91$ \\
\hline FW (g) & 3.412 & $<0.001$ & $\mathrm{NI} 283$ & 2141.67 & NI219 & 526.64 & $980.58 \pm 498.06$ \\
\hline FH (cm) & 3.097 & $<0.001$ & NI106 & 22.83 & $\mathrm{NI} 202$ & 10.38 & $14.28 \pm 4.28$ \\
\hline FD $(\mathbf{c m})$ & 2.659 & 0.001 & NI354 & 17.16 & NI174 & 9.83 & $12.20 \pm 2.22$ \\
\hline $\mathrm{CD}(\mathrm{cm})$ & 2.540 & 0.001 & $\mathrm{NI} 354$ & 12.64 & $\mathrm{NI} 215$ & 6.53 & $8.52 \pm 1.80$ \\
\hline NS & 2.317 & 0.003 & $\mathrm{NI} 283$ & 371 & $\mathrm{NI} 224$ & 159.69 & $249.89 \pm 85.68$ \\
\hline 100-SW (g) & 4.533 & $<0.001$ & $\mathrm{NI} 283$ & 30.99 & NI219 & 10.95 & $16.29 \pm 5.58$ \\
\hline HI & 1.423 & 0.124 & NI304 & 0.06 & NI174 & 0.03 & $0.04 \pm 0.01$ \\
\hline SW (g) & 3.536 & $<0.001$ & $\mathrm{NI} 283$ & 25.98 & $\mathrm{NI} 249$ & 17.96 & $41.19 \pm 23.32$ \\
\hline
\end{tabular}


International Journal of Advances in Scientific Research and Engineering (ijasre), Vol 5 (7), July-2019

TE: Emergence time; FM: First fruit maturity; NB: Number of branches; PL: Plant length; SR: Sex ratio; NF: Number of fruits; FW: Fruit weight; FH: Fruit height; FD: Fruit diameter; CD: Diameter cavity of the lodge of seeds; NS: Number of seeds per fruit; 100-SW: 100- seeds weight; HI: Harvest index; SW (SY): Seed Yield; F: Frequency; P: Probability

\subsection{Analysis of Agro-morphological Variability by Origin}

The multivariate analysis of variance (MANOVA) performed for all the agro-morphological characters taken simultaneously showed a very highly significant difference $(F=147.024, P<0.001)$ between the accessions according to their origin. The specific characteristics that differentiated the three zones were revealed by the analysis of variance (ANOVA). As shown by the results grouped in Table 4, all traits, except emergence time (TE), number of branches (NB), number of fruits (NF) and sex ratio (SR), showed a highly significant difference $(P<0.001)$ between the accessions of the three zones (South, Central and East).

Table 4. Mean values and deviation $( \pm)$ of 14 morphological characters measured in considering origin of accessions in the cultivars of Lagenaria siceraria

\begin{tabular}{cccccc}
\hline \hline Characters & South & Center & East & F & \multicolumn{1}{c}{ P } \\
\hline TE & $5.178 \pm 0.387^{\mathrm{a}}$ & $5.118 \pm 0.332^{\mathrm{a}}$ & $5.184 \pm 0.393^{\mathrm{a}}$ & 0.077 & $0.201^{\mathrm{NS}}$ \\
NB & $1.556 \pm 0.503^{\mathrm{a}}$ & $1.235 \pm 0.437^{\mathrm{a}}$ & $1.342 \pm 0.481^{\mathrm{a}}$ & 1.328 & $0.175^{\mathrm{NS}}$ \\
PL (m) & $6.176 \pm 2.513^{\mathrm{b}}$ & $5.215 \pm 2.258^{\mathrm{b}}$ & $11.158 \pm 3.762^{\mathrm{a}}$ & 5.68 & $<0.001^{* * *}$ \\
FM (d) & $104.267 \pm 2.349^{\mathrm{b}}$ & $108.588 \pm 3.144^{\mathrm{b}}$ & $127.000 \pm 0.000^{\mathrm{a}}$ & 384.064 & $<0.001^{* * *}$ \\
NF & $4.222 \pm 2.819^{\mathrm{a}}$ & $1.824 \pm 1.185^{\mathrm{a}}$ & $3.684 \pm 3.264^{\mathrm{a}}$ & 1.435 & $0.118^{\mathrm{NS}}$ \\
FW (g) & $665.451 \pm 177.630^{\mathrm{c}}$ & $866.863 \pm 523.931^{\mathrm{b}}$ & $1401.480 \pm 452.941^{\mathrm{a}}$ & 7.66 & $<0.001^{* * *}$ \\
FH (cm) & $11.597 \pm 1.379^{\mathrm{c}}$ & $14.316 \pm 4.679^{\mathrm{b}}$ & $17.322 \pm 4.359^{\mathrm{a}}$ & 5.276 & $<0.001^{* * *}$ \\
FD (cm) & $11.235 \pm 0.990^{\mathrm{b}}$ & $10.815 \pm 0.959^{\mathrm{b}}$ & $14.009 \pm 2.509^{\mathrm{a}}$ & 5.348 & $<0.001^{* * *}$ \\
CD (cm) & $7.760 \pm 0.883^{\mathrm{b}}$ & $7.275 \pm 0.718^{\mathrm{b}}$ & $9.982 \pm 2.005^{\mathrm{a}}$ & 5.053 & $<0.001^{* * *}$ \\
NS & $198.545 \pm 49.83^{\mathrm{c}}$ & $237.273 \pm 64.00^{\mathrm{b}}$ & $320.511 \pm 77.658^{\mathrm{a}}$ & 4.521 & $<0.001^{* * *}$ \\
100-SW (g) & $12.966 \pm 1.73^{\mathrm{b}}$ & $13.819 \pm 3.845^{\mathrm{b}}$ & $21.337 \pm 5.571^{\mathrm{a}}$ & 7.438 & $<0.001^{* * *}$ \\
HI & $0.038 \pm 0.010^{\mathrm{a}}$ & $0.041 \pm 0.013^{\mathrm{a}}$ & $0.047 \pm 0.01^{\mathrm{a}}$ & 2.676 & $0.135^{\mathrm{NS}}$ \\
SR & $0.113 \pm 0.064^{\mathrm{a}}$ & $0.087 \pm 0.043^{\mathrm{a}}$ & $0.101 \pm 0.053^{\mathrm{a}}$ & 1.280 & $0.206^{\mathrm{NS}}$ \\
SW (g) & $25.095 \pm 8.140^{\mathrm{a}}$ & $33.365 \pm 18.071^{\mathrm{b}}$ & $64.413 \pm 18.327^{\mathrm{c}}$ & 10.555 & $<0.001^{* * *}$ \\
\hline \hline
\end{tabular}

TE: Emergence time; FM: First fruit maturity; NB: Number of branches; PL: Plant length; SR: Sex ratio; NF: Number of fruits; FW: Fruit weight; FH: Fruit height; FD: Fruit diameter; CD: Diameter cavity of the lodge of seeds; NS: Number of seeds per fruit; 100-SW: 100- seeds weight; HI: Harvest index; SW (SY) : Seed Yield; F: Frequency; P: Probability; NS: Not significant; *** Very significant

The results in Table 4 show a similarity for four characters (TE, NB, NF, SR) between the three zones. A total differentiation was observed between the accessions of the three zones for five characters (FW, FH, NS, HI, SY).

Southern accessions had the lowest average values for yield traits. While eastern accessions, on the other hand, had the highest average values.

Eastern accessions differed distinctly from the South and Central accessions at the ten-fold level, namely the length of the plant $(\mathrm{PL})$, the fruit ripening time (FM), the fruit weight $(\mathrm{FW})$, fruit height $(\mathrm{FH})$, fruit diameter (FD), diameter cavity lodge of seed (CD), number of seeds per fruit (NS), fruit weight (FW), 100-seed weight (100-SW), seed yield (SW) for 10 of the 14 characters analyzed (Table 4).On the other hand, those in the South and Center showed both similarities and divergences. The accessions from the South and the Center were identical for the five characters that are, length of the plant (PL), fruit ripening time (FM), diameter of the fruit (FD), cavity of the box seeds (CD) and 100-seed weight (100-SW). There were differences in fruit weight (FW), fruit height (FH), seed number (NS), harvest index (HI) and seed weight (SW) (Table 4).

\subsection{Correlations Between Agro-morphological Characters}

The majority of observed correlations are highly significant. The highest are those which associate the characters of the yield between them. Significant correlations are observed between the vegetative traits on the one hand and between them and yield traits on the other hand. The duration of emergence also has negative correlations with the yield traits.

There are weak and negative correlations between some yield traits, such as fruit number and fruit height, and 100-seed weight and harvest index (Table 5). The highest correlations were observed between seed weight and number of seeds $(r=0.903)$ and fruit weight $(r=0.864)$. 
International Journal of Advances in Scientific Research and Engineering (ijasre), Vol 5 (7), July-2019

Table 5. Correlation Matrix of the 14 agro-morphological variables used in the study of the morphological diversity of $L$. siceraria

\begin{tabular}{|c|c|c|c|c|c|c|c|c|c|c|c|c|c|c|}
\hline & TE & NB & PL & FM & NF & FW & FH & FD & CD & NS & 100-SW & HI & SR & SW (SY) \\
\hline TE & 1.000 & 0.046 & 0.043 & 0.025 & -0.022 & -0.077 & -0.060 & -0.034 & 0.026 & -0.045 & 0.091 & 0.115 & $0.282 * *$ & -0.013 \\
\hline NB & & 1.000 & -0.061 & -0.179 & 0.073 & -0.187 & $-0.247 * *$ & -0.144 & -0.111 & -0.093 & -0.087 & 0.139 & -0.025 & -0.116 \\
\hline PL & & & 1.000 & $0.647^{* *}$ & $0.318^{* *}$ & $0.509^{* *}$ & $0.461 * *$ & $0.511 * *$ & $0.486 * *$ & $0.533 * *$ & $0.472^{* *}$ & $0.259^{* *}$ & 0.047 & $0.586^{* *}$ \\
\hline NF & & & & & 1.000 & 0.042 & -0.007 & 0.093 & 0.092 & 0.076 & -0.045 & -0.012 & $0.296 * *$ & 0.045 \\
\hline FW & & & & & & 1.000 & $0.860 * *$ & $0.794 * *$ & $0.710 * *$ & $0.779 * *$ & $0.821 * *$ & 0.010 & -0.067 & $0.864 * *$ \\
\hline FH & & & & & & & 1.000 & $0.743^{* *}$ & $0.681 * *$ & $0.720 * *$ & $0.701^{* *}$ & 0.018 & -0.065 & $0.731 * *$ \\
\hline NS & & & & & & & & & & 1.000 & $0.687^{* *}$ & $0.484^{* *}$ & -0.123 & $0.903 * *$ \\
\hline 100-SW & & & & & & & & & & & 1.000 & $0.280^{* *}$ & -0.047 & $0.838^{* *}$ \\
\hline HI & & & & & & & & & & & & 1.000 & -0.153 & $0.466^{* *}$ \\
\hline $\mathbf{S R}$ & & & & & & & & & & & & & 1.000 & -0.107 \\
\hline SW (SY) & & & & & & & & & & & & & & 1.000 \\
\hline
\end{tabular}

TE: Emergence time; FM: First fruit maturity; NB: Number of branches; PL: Plant length; SR: Sex ratio; NF: Number of fruits; FW: Fruit weight; FH: Fruit height; FD: Fruit diameter; CD: Diameter cavity of the lodge of seeds; NS: Number of seeds per fruit; 100-SW: 100- seeds weight; HI: Harvest index; SW (SY) : Seed Yield; F: Frequency; P: Probability; ** Very significant 


\subsection{Principal Component Analysis}

Principal component analysis (PCA) of accessions is done on the basis of agro-morphological characters. It showed that the first four axes with eigenvalues higher than 1, explain respectively $55.09 \%, 11.86 \%, 10.3 \%$ and $7.68 \%$ of the variability, or $84.93 \%$ of the total variability (Table 6).

Axis $1(55.09 \%)$ is mainly influenced by nine traits, including plant length, ripeness of fruit, fruit weight, fruit height, fruit diameter, cavity of seeds lodge, the number of seeds, the 100-seed weight and seeds yield. Analysis of the characters involved in the formation of this axis 1 reveals that it is characteristic of the production and the vigor of the plants. Axis 2 (11.86\%) defines vegetative and phenological development. Axis $3(10.3 \%)$ and axis $4(7.68 \%)$ are weakly correlated to all variables. Axis 3 is negatively correlated with the harvest index. Table 6 presents the matrix of own values and factorial weights of the variables on the first four axes of the principal component analysis (PCA).

Table 6. Matrix of own values and correlations between variables and axes released by the Principal Component Analysis on accessions of Lagenaria siceraria.

\begin{tabular}{ccccc}
\hline \hline & Axis 1 & Axis 2 & Axis 3 & Axis 4 \\
Own values & 7.71 & 1.66 & 1.44 & 1.07 \\
\% Inertia & 55.09 & 11.86 & 10.30 & 7.68 \\
\% Cumulative inertia & 55.09 & 66.95 & 77.25 & -0.57 \\
\hline TE & 0.00 & 0.63 & -0.34 & 0.36 \\
NB & -0.40 & 0.31 & -0.60 & -0.07 \\
PL & 0.84 & 0.16 & 0.04 & -0.09 \\
FM & 0.90 & 0.00 & -0.18 & 0.66 \\
NF & 0.20 & 0.50 & 0.33 & -0.09 \\
FW & 0.94 & -0.11 & 0.14 & -0.14 \\
FH & 0.87 & -0.18 & 0.23 & 0.11 \\
FD & 0.90 & 0.22 & 0.16 & 0.15 \\
CD & 0.84 & 0.31 & 0.10 & 0.12 \\
NS & 0.93 & -0.19 & -0.17 & -0.10 \\
100-SW & 0.95 & 0.03 & -0.11 & 0.21 \\
HI & 0.38 & -0.07 & -0.79 & -0.18 \\
SR & -0.07 & 0.80 & 0.15 & 0.01 \\
SY & 0.97 & -0.08 & -0.16 & . \\
\hline \hline
\end{tabular}

In the analysis of the ordination of variables, only axis 1 and 2 with the greatest variability (66.95\%) were considered. The projections of the variables (Figure 1) and accessions (Figure 2) in the factorial plane were used to analyze the morphological variability. The projection of the variables made it possible to note that nine variables (FM, PL, FW, FH, FD, CD, NS, 100-SW, and SW) are positively correlated with axis 1 . On the other hand, only one variable (SR) defines axis 2.

The projection of individuals in the factorial plane 1-2 highlights two large groups. The arrangement of the accessions in this plan shows a structuring according to their geographical origin (Figure 2). Axis 1 contrasts Eastern accessions (Polygon I) with Southern accessions (Polygon II). Polygon I, grouping eastern accessions, is located in the positive part of axis 1 . The scatter plot of polygon II is distributed on both sides in the negative part of axis 1. The Center accessions (polygon III) are essentially distributed on either side of the negative part of axis 2. This polygon III has an overlap with polygon II. At the level of each large group observed through the scatter circles, the accessions are distributed along the axis 2 , so that they are found on both the positive and negative sides of this axis. 


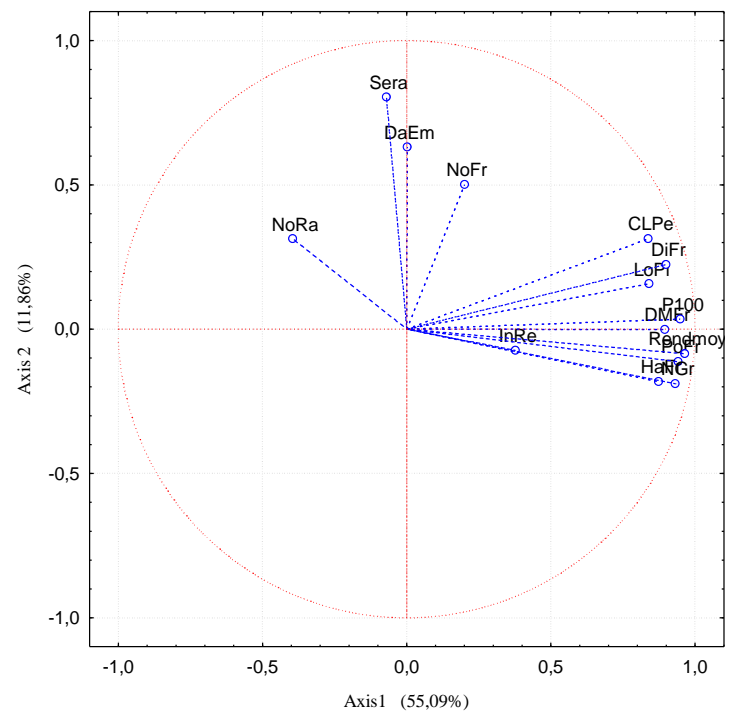

Figure 1. Projection of variables in the factorial plan 1-2 of the PCA carried out

TE: Emergence time; FM: First fruit maturity; NB: Number of branches; PL: Plant length; SR: Sex ratio; NF: Number of fruits; FW: Fruit weight; FH: Fruit height; FD: Fruit diameter; CD: Diameter cavity of the lodge of seeds; NS: Number of seeds per fruit; 100-SW: 100- seeds weight; HI: Harvest index; SW (SY): Seed Yield

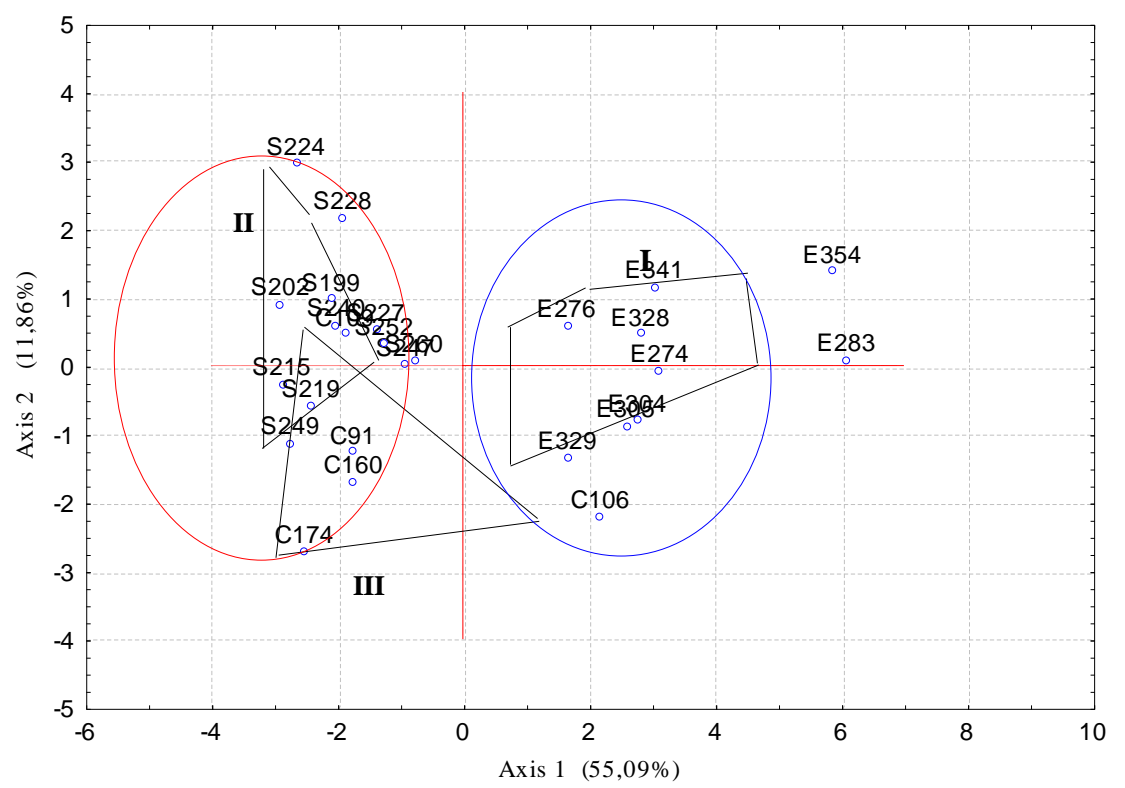

Figure 2. Distribution of $26 \mathrm{~L}$. siceraria accessions from three collection areas in Plan 1-2 of the PCA.

The arrangement of the accessions in this plan 1-2 shows a structuring according to their geographical origin (Figure 2). Axis 1 opposes the southern accessions characterized by their precocity and the low values of the other measured parameters to the accessions of East. At the level of each group, the accessions are scattered along axis 2, so that they are found on both the positive and negative sides of this axis. The center's accessions found in both sets did not show any particular structuring. They are nevertheless all grouped in the negative part of axis.

\subsection{Agro-morphological Divergences}

Table 6 representing the resulting classification matrix of the Discriminant Factorial Analysis indicates that the accessions are correctly classified in their area of origin. The percentage of well-ranked individuals ranges from 60 to $100 \%$ with an average of $83.89 \%$. Indeed, this analysis proposes a reclassification of accessions. Thus, of the 12 accessions in the South, 11 are recognized as actually belonging to this zone, ie $91.67 \%$ of correct classification. Three of the five accessions in the center are recognized as 
International Journal of Advances in Scientific Research and Engineering (ijasre), Vol 5 (7), July-2019

correctly classified in this zone, ie $60 \%$. One accession is recognized as part of the South and another of the East. Eastern accessions have all been recognized as belonging to this area.

Table 6. Correct classification matrix resulting from AFD ordering accessions of the three zones

\begin{tabular}{lcccc}
\hline \hline Origin & Individus bien classés $\mathbf{( \% )}$ & South & Center & East \\
\hline South & 91.67 & 11 & 1 & 0 \\
Center & 60 & 1 & 3 & 1 \\
East & 100 & 0 & 0 & 9 \\
Total & 83.89 & 12 & 4 & 10 \\
\hline \hline
\end{tabular}

\subsection{Discriminant Variable}

The Discriminant Factor Analysis confirms that axes 1 and 2 account for most of the observed dispersion, ie $66.95 \%$ of the total variability. The structuring of accessions according to the collection zones revealed by the PCA is confirmed by AFD. Wilk's Lambda test indicates in order of decreasing discriminating power that four of the characters most discriminate accessions according to their geographical origin (Table 7). These parameters are mostly characteristic of yield (fruit weight, fruit diameter, and seed weight or yield), and phenology (fruit ripening time).

Table 7. Lambda of wilk and corresponding probability of quantitative characters more discriminating between accessions according to their origin

\begin{tabular}{clccc}
\hline \hline Order & \multicolumn{1}{c}{ Characters } & Wilk's Lambda $(\boldsymbol{\Lambda})$ & $\boldsymbol{F}$ & $\boldsymbol{P}$ \\
\hline $\mathbf{1}$ & Fruit ripening time (FM) & 0.079 & 529.004 & $<0.001$ \\
$\mathbf{2}$ & Fruit weight (FW) & 0.848 & 8.145 & 0.001 \\
$\mathbf{3}$ & Fruit diameter (FD) & 0.870 & 6.804 & 0.002 \\
$\mathbf{4}$ & Seed yield (SY) & 0.925 & 3.703 & 0.028 \\
\hline \hline
\end{tabular}

\subsection{Accessions Classification and Identification of Diversity Groups}

Truncation of the dendogram performed at 10 units in terms of eucludian distance provides a more refined classification of phenotypic diversity groups. Thus analysis of dendogram resulting from hierarchical ascending classification (HAC) reveals two groups (I and II) with respectively 16 and 10 accessions (Figure 3). In addition, the Mahalanobis distance separating the two groups is very highly significant (Table 8). The relevance of the groups resulting from the CAH was appreciated by a DFA (Figure 4). This figure presents two groups of diversity according to the origin. The two groups observed are very identical to those obtained with PAC and HAC. 


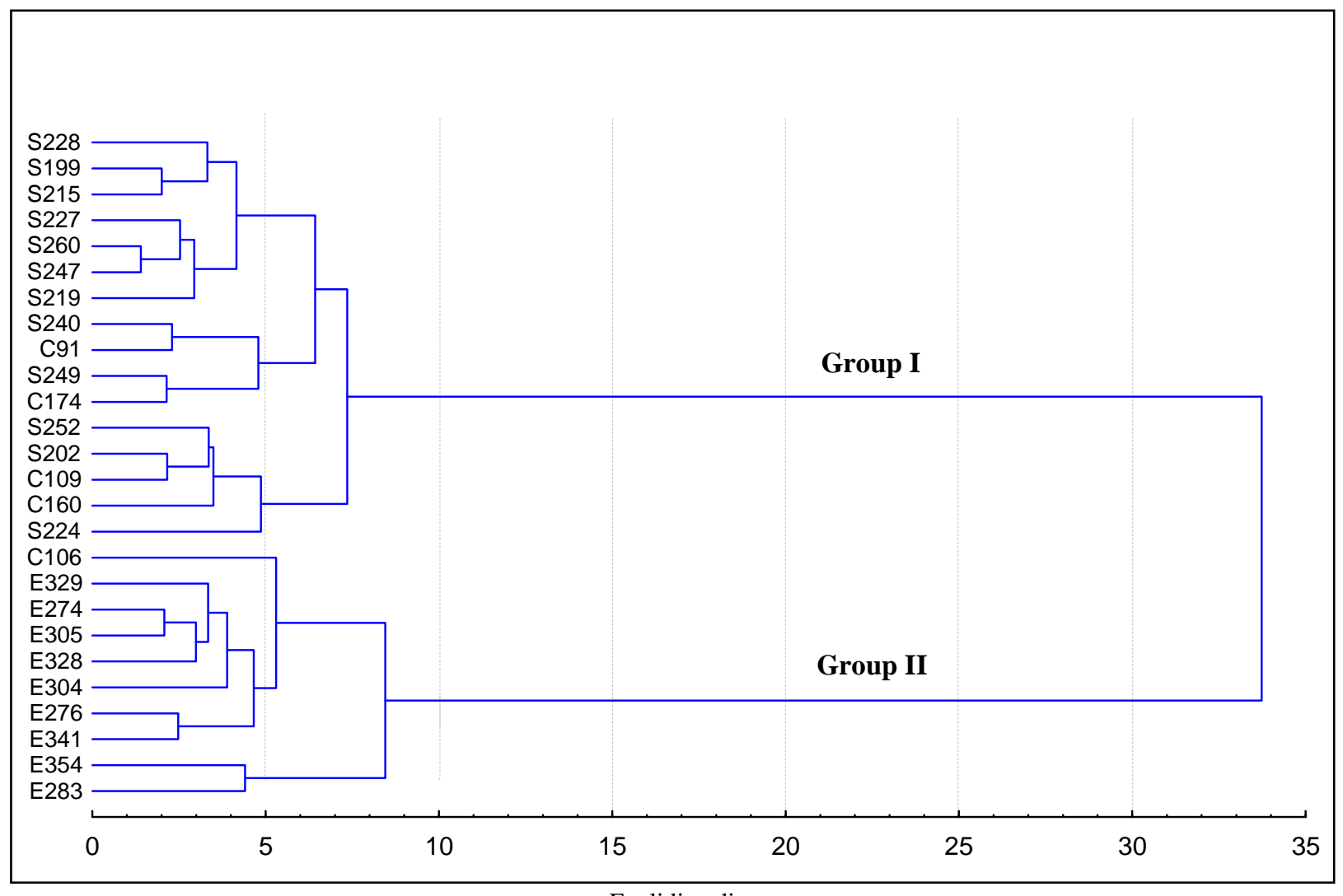

Euclidian distance

Figure 3:

Ward ascending hierarchical classification of $26 \mathrm{~L}$. siceraria accessions collected in 3 zones of Côte d'Ivoire. S: South; C:

Center and E: East.

Table 1. Matrix of Mahalanobis distances calculated between the two phenotypic classes of Lagenaria siceraria accessions and the significance of these distances.

\begin{tabular}{lll}
\hline \hline & Group I & Group II \\
\hline Group I & 0 & $167.67^{* * *}$ \\
Group II & & 0 \\
\hline
\end{tabular}

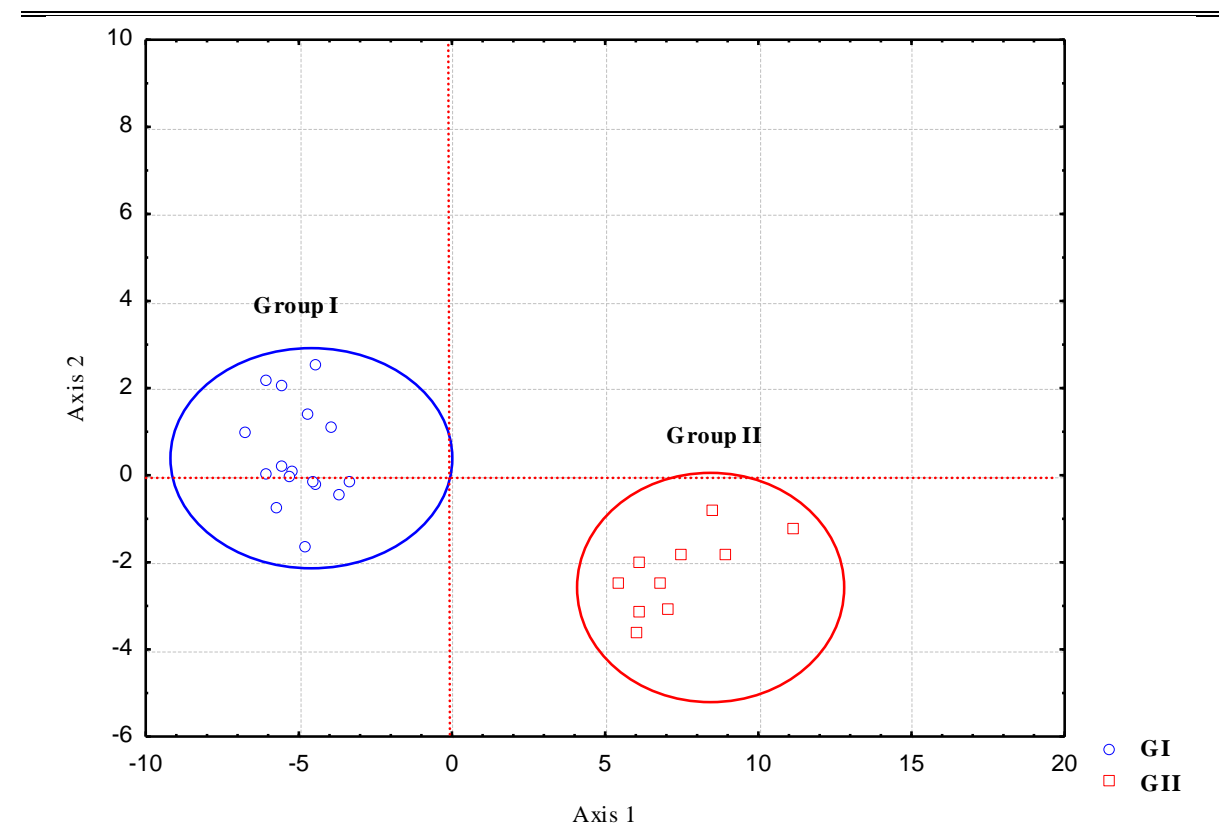

Figure 4. Representation of the 2 phenotypic diversity groups in the factorial plane defined by axes 1 and 2 of DFA 


\subsection{Groups Typology and Phenotypic Diversity}

The group I is represented by 16 accessions originating in the South and Central areas (Figure 6). This set includes all Southern accessions (12) and four accessions of the Center. Group I accessions are characterized by an early development cycle marked by physiological maturity after $105.06 \pm 3.11$ days. Some individuals are particularly early and mature before 100 days. In group I, with the exception of the number of branches, the number of fruits, and the sex ratio, all the other 11 characters observed had the smallest mean values. This group is characterized by small fruits (Table 8).

The group II comprises 10 accessions. This group is dominated by Eastern accessions, of which there are 9 with access to the Center (Figure 7). This group is characterized by a longer development cycle (127 days). In this group, the seed yield, the number of seeds and the 100-seed weight have higher mean values than those of group I. This group is also characterized by the highest mean values in terms of fruit weight $(1436.93 \pm 72.37)$, yield $(64.12 \pm 2.45), 100$-seed weight $(21.47 \pm 0.77)$ and number of seeds $(318.45 \pm 10.13)$. In this group the best mean values are also observed in fruit diameter $(16.67 \pm 0.7)$, diameter cavity of the lodge of seeds $(11.65 \pm 1.41)$ and fruit size $(20.21 \pm 2.14)$ (Table 8). A significant difference was observed between the two groups. This differentiation is in terms of yield parameters (fruit weight, number of seeds, 100-seed weight and fruit size).

Table 9. Basic statistics of the agro-morphological variables of the accessions groups resulting from the hierarchical classification of the 26 accessions of Lagenaria siceraria

\begin{tabular}{|c|c|c|c|c|c|c|}
\hline \multirow[b]{2}{*}{ Characters } & \multirow[b]{2}{*}{ Group I } & \multirow[b]{2}{*}{$\mathrm{CV}$} & \multicolumn{4}{|c|}{ Statistics } \\
\hline & & & Group II & CV & $\boldsymbol{F}$ & $P$ \\
\hline TE (d) & $5.16 \pm 0.22^{\mathrm{a}}$ & 0.04 & $5.18 \pm 0.20^{\mathrm{a}}$ & 0.04 & 0.07 & $0.79^{\mathrm{NS}}$ \\
\hline NB & $1.49 \pm 0.28^{\mathrm{a}}$ & 0.19 & $1.29 \pm 0.23^{\mathrm{a}}$ & 0.18 & 3.44 & $0.075^{\mathrm{NS}}$ \\
\hline PL (m) & $5.71 \pm 1.67^{\mathrm{b}}$ & 0.28 & $11.24 \pm 2.42^{\mathrm{a}}$ & 0.22 & 47.52 & $0.001^{* * *}$ \\
\hline FM (d) & $105.06 \pm 3.11^{b}$ & 0.03 & $125.40 \pm 5.42^{\mathrm{a}}$ & 0.04 & 149.24 & $0.001^{* * *}$ \\
\hline NF & $3.40 \pm 1.7^{\mathrm{b}}$ & 0.5 & $3.56 \pm 1.56^{\mathrm{a}}$ & 0.44 & 0.062 & $0.81^{\mathrm{NS}}$ \\
\hline FW (g) & $687.80 \pm 134.79^{b}$ & 0.20 & $1436.93 \pm 330.75^{\mathrm{a}}$ & 0.23 & 65.93 & $0.001^{* * *}$ \\
\hline FH $(\mathbf{c m})$ & $11.87 \pm 1.04^{\mathrm{b}}$ & 0.08 & $17.88 \pm 2.64^{\mathrm{a}}$ & 0.15 & 67.48 & $0.001^{* * *}$ \\
\hline FD (cm) & $11.14 \pm 0.76^{\mathrm{b}}$ & 0.07 & $13.73 \pm 1.74^{\mathrm{a}}$ & 0.13 & 27.56 & $0.001^{* * *}$ \\
\hline CD (cm) & $7.66 \pm 0.64^{\mathrm{b}}$ & 0.08 & $9.6 \pm 1.52^{\mathrm{a}}$ & 0.16 & 20.84 & $0.001^{* * * *}$ \\
\hline NS & $204.67 \pm 31.13^{\mathrm{b}}$ & 0.15 & $318.45 \pm 33.4^{\mathrm{a}}$ & 0.10 & 77.80 & $0.001^{* * *}$ \\
\hline 100-SW (g) & $12.79 \pm 0.95^{\mathrm{b}}$ & 0.07 & $20.07 \pm 3.76^{\mathrm{a}}$ & 0.18 & 78.80 & $0.001^{* * *}$ \\
\hline HI (\%) & $3.9 \pm 0.7^{\mathrm{b}}$ & 0.18 & $4.5 \pm 0.6^{\mathrm{a}}$ & 0.13 & 6.50 & $0.017^{*}$ \\
\hline SR & $0.11 \pm 0.04^{\mathrm{a}}$ & 0.36 & $0.10 \pm 0.03^{\mathrm{a}}$ & 0.30 & 0.36 & $0.55^{\mathrm{NS}}$ \\
\hline SW or SY (g) & $25.61 \pm 5.07^{\mathrm{b}}$ & 0.20 & $64.12 \pm 10.83^{\mathrm{a}}$ & 0.17 & 151.81 & $0.001^{* * *}$ \\
\hline
\end{tabular}

TE: Emergence time; FM: First fruit maturity; NB: Number of branches; PL: Plant length; SR: Sex ratio; NF: Number of fruits; FW: Fruit weight; FH: Fruit height; FD: Fruit diameter; CD: Diameter cavity of the lodge of seeds; NS: Number of seeds per fruit; 100-SW: 100- seeds weight; HI: Harvest index; SW (SY) : Seed Yield; F: Frequency; P: Probability; ** Very significant

\section{DISCUSSION}

The coefficients of variation observed for a significant number of characters indicate the presence of high variability within local accessions of Lagenaria siceraria. Importance of the phenotypic variability observed reflects expression of a strong genotypic heterogeneity. The strong heterogeneity of the coefficient of variation observed in the present study suggests that the collection of L. siceraria from Nangui Abrogoua University can serve as a working collection for the varietal improvement of this species, focusing in particular on agronomic performances. In this context, accessions expressing the best values of yield parameters can serve parental genotypes. Correlation analysis indicated a positive relationship between vegetative traits and plant yield traits. The negative correlation between fruit size and the number of fruits carried by a plant has also been reported in melon [20] and squash [21]. Correlations are an indispensable indicator for enhancers in the selection of traits to be included in breeding programs. The results of this study show that the parameters that contribute significantly to the distinction of individuals are characteristic of the yield. The strong contribution of fruit size and fruit weight to morphological variability in this species has already been reported [22, 23, and 12]. The size of the fruit, the weight of the fruit and the weight of the seeds can serve as indices of choice for accessions during collection missions. Also, the results of this study allowed understanding why in most rural communities in 
Africa, local breeds of L. siceraria are differentiated by reference to the size and weight of the fruit [14]. The parameters involved in the agro-morphological variability observed during this study are similar to those observed in several other studies [24, 14], demonstrating that in domesticated species, the differences morphological traits are often based on agronomic traits. Within the cucurbits, a significant contribution of characters measured on the fruit to the morphological variability was also observed in the watermelon [23, 24, and 14], the bitter gourd [25] and the calabash [26].

The results of PCA showed a distribution of accessions according to their agro-morphological performance and to a large extent according to their geographical origin. DFA and HCA confirmed not only the significant morphological variability, but also its structuring according to agronomic performance and collection areas. The high representativeness of the first two axes of PCA $(69.95 \%)$ shows existence of a strong genotypic and phenotypic organization of the studied material. PCA structures the accessions according to the duration of maturation in early and late groups. With CAH, two large diversity groups have been identified, clearly defining two phenological types (early and late). The eastern zone presents a great variability with the separation of accessions into two sets of diversity according to the agro-morphological performance of accessions. This area is mainly characterized by long-cycle accessions with strong vegetative characteristics at high yield. The diversity group consisting of accessions with a short development cycle with weak vegetative characteristics and a low yield includes accessions from the southern zone, mainly with 4 accessions from the central zone. The agro-morphological and phenological dissimilarities observed between the different groups of phenotypic diversity suggest that accessions are maintained under very different evolutionary processes in their respective agrosystems. Agrosystems may exert very variable selective pressures on genotypes [27, 11]. These evolutionary factors could be the causes of agro-morphological and phenological differentiation observed between accessions. This constant evolution, influenced by the pedological, climatic and anthropic factors in the different agro ecosystems, confers to accessions their own characteristics [28]. The presence of some accessions in different groups of diversity that are not their own suggests exchanges of seeds between different areas. These exchanges would be made by migration or informal transactions on the markets of major cities of the country. In particular, the presence of Center accessions in the Southern and Eastern accessions group is indicative of gene flow (via seed) from these areas to the Center. Indeed, in Côte d'Ivoire, it has been shown that the oleaginous form of L. siceraria is mainly produced in the South, East and North zones, the Center producing more regularly and predominantly the species Citrullus lanatus [8].The trend observed during this study can also be linked to peasant selection, which mainly takes into account agronomic performance and especially the yield per plant, in particular the size and weight of the fruit. These characteristics, which are the most discriminating, are also the most remarkable at the level of the cultures and seem to generally influence the choices of the peasants. The grouping of accessions within each diversity group generally shows a structuring of the agro-morphological variability according to the size of the fruit and the weight of the fruit and seems to confirm the peasant classification. According to [29], identifying the peasant unit of diversity management as an analytic unit can be an important tool for the evolution of diversity.

\section{CONCLUSION}

The objective of this study was to search in Ivorian cultivars of the oleaginous form of L. siceraria, the morphological characters that best explain the varietal diversity reported by the producers and to see its possible links with the production areas. Various information collected allows a better knowledge of this species of oilseed cucurbit cultivated in Côte d'Ivoire thus revealing the characters to be taken into account for the constitution of a gene bank. This study was carried out in order to verify the existence of diversity within these local accessions. The study was also initiated to look for the morphological characters that best explain the varietal diversity reported by the producers and to see its possible links with the collection areas. The most relevant variables that describe the variability between groups are fruit size, fruit weight, seed number, and seed weight. These analyzed characters can thus constitute basic criteria to differentiate the accessions and to be used in studies of morphological diversity of $L$. siceraria. Since the varieties evaluated in this study are on different origins, the need to establish a seed bank is essential in Côte d'Ivoire. This bank will gather the maximum of varieties that will be analyzed to estimate their morphological and agronomic diversity on the basis of the most variable characters observed in this study. The selection strategies that can be considered for the genetic improvement of $L$. siceraria require a good knowledge of the genetic diversity that has accumulated within traditional varieties as a result of natural and human selections. The morphotypes cultivated by farmers deserve a thorough investigation to better discriminate them. Because quantitative traits are influenced by environment, multi-site trials should be conducted at different seasons to better appreciate the stability of the differences or similarities observed in this study. The study of the most discriminating traits in relation to yield is a source to explore to consider improving the species.

\section{REFERENCES}

[1]. Mayers S., Massawe F.S., Alderson P.G., Roberts J.A., Azam-Ali N.S. \& Hermann M. The potential for underutilized crops to improve security of food production. Journal of Experimental Botany, vol.63 (3), 2012, pp. 1075-1079. 
[2]. Bohra A., Jha U.C., Kishor P.B.K., Pandey S. \& Singh N.P. Genomics and molecular breeding in lesser explored pulse crops: Current trends and future opportunities. Biotechnology Advances, vol. 32, 2014, pp. 1410-1428.

[3]. Ojeniyi S.O., Adejoro S.A., Ikotun O.and Amusan O. Soil and plant nutrient composition, growth and yield of cassava as influenced by integrated application of NPK fertilizer and poultry manure. New York Science Journal, vol. 5 (9), 2012 pp. 62-68.

[4]. Achigan-Dako E.G., Fanou N., Kouke A., Avohou H., Vodouhe R.S. \& Ahanche A. Evaluation agronomique de trois espèces de Egusi (Cucurbitaceae) utilisées dans l'alimentation au Bénin à l'élaboration d'un modèle de prédiction du rendement. Biotechnologie, Agronomie, Société et environnement, vol. 10 (2), 2006, pp.121-129.

[5]. Zoro Bi I.A., Koffi K.K., Djè Y., Malice M. and Baudoin J.P. Biodiversity of cucurbits consomed as sauce thickener in Ivory Coast: a capital resource for the economic prosperity of rural women. In: Segers H. P. D. \& (Eds.) B.E. (eds) Tropical Biodiversity: Science, data, conservation. GBIF, Brussels (Belgium), 2005, p 169.

[6]. Loukou A.L., Lognay G., Barthelemy J-P., Maesen P., Baudoin J-P. and Zoro Bi I.A. Effect of harvest time on seed oil and protein contents and compositions in the oleaginous gourd Lagenaria siceraria (Molina) Standl. Journal of Science of Food and Agriculture, vol. 91, 2011, pp. 2073-2080.

[7]. Loukou A.L, Lognay G., Baudoin J-P., Kouamé L.P. \& Zoro Bi I.A. Effect of fruit maturity on oxydative stability of Lagenaria siceraria (Molina) Standl.seed oil extracted with hexane Journal of Food Biochemistry, 2012.

[8]. Zoro Bi I.A., Koffi K.K., Djè Y., Malice M. and Baudoin J.P. Indigenous cucurbit of Côte d'Ivoire: a review of their genetic resources Science \& Nature, vol.3 (1), 2006, pp. 1-9.

[9]. Zoro Bi I.A., Koffi K. and Djè Y. Caractérisation botanique et agronomique de trois espèces de cucurbites consommées en sauce en Afrique de l'Ouest: Citrullus sp.,Cucumeropsis mannii Naudin et Lagenaria siceraria (Molina) Standl. Biotechnologie, Agronomie Société et Environnement, vol.7 (3-4), 2003, pp. 189-199.

[10]. Hawkes J.G. The importance of genetic resources in plant breeding.Biological Journal of the Linnean Society, vol.43, 1991, pp. 3-10.

[11]. Zoro Bi I.A., Koffi K. \& Djè Y. Caractérisation botanique et agronomique de trois espèces de cucurbites consommées en sauce en Afrique de l'Ouest: Citrullus sp.,Cucumeropsis mannii Naudin et Lagenaria siceraria (Molina) Standl. Biotechnologie, Agronomie Société et Environnement, vol. 7 (3-4), 2003, pp. 189-199.

[12]. Koffi K.K., Anzara G.K., Malice M., Djè Y., Bertin P., Baudoin J.P. and Zoro Bi I.A. Morphological and allozyme variation in a collection of Lagenariasiceraria (Molina) Standl.from Côte d'Ivoire. Biotechnology Agronomy Society and Environment, vol. 13 (2), 2009, pp. 257-270.

[13]. Bisognin D.A. Origin and evolution of cultivated cucurbits. Ciencia Rural Santa Maria 32 (4), 2002 , pp.715-723.

[14]. Morimoto Y., Maundu P., Fujimaki H. and Morishima H. Diversity of landraces of the white-flowered gourd (Lagenaria siceraria) and its wild relatives in Kenya: fruit and seed morphology. Genetic Resources and Crop Evolution vol. 52, 2005, pp. 737-747.

[15]. Sadiki M. and Jarvis D. Conservation in situ de la diversité génétique des cultures par sa gestion à la ferme dans les agroécosystèmes marocains. Les Actes $d u$ BRG, vol. 5, 2005, pp. 445-464.

[16]. Morimoto Y, Maundu P, Makoto K, Hiroshi F and Hiroko M. RAPD Polymorphism of the White-Flowered Gourd (Lagenaria siceraria (Molina) Standl.) Landraces and its Wilds Relatives in Kenya. Gentic Resources and Crop Evolution, vol. 53 (5), 2006, pp. 963-974.

[17]. Decker-Walters D., Staub J., Lopez-Sesé A. Nakata E. Diversity in landraces and cultivars of bottle gourd (Lagenaria siceraria, Cucurbitaceae) as assessed by random amplified polymorphic DNA. Genetic Resources and Crop Evolution 48 (4), 2001, pp. 369-380.

[18]. Achigan-Dako E.G. Caractérisation morphologique et analyse du niveau de ploïdie des Cucurbitacées de l'espèce Lagenaria siceraria prospectée au Benin et au Togo. Abidjan (Côte d'Ivoire): Université de Cocody, 2002, 52 p.

[19]. StatSoft STATISTICA, logiciel d'analyse de données. 2005, 7.1. Edition. www.statsoft.fr.

[20]. Ban D., Goreta S. \& Borosic J. Plant spacing and cultivar affect melon growth and yield components. Scientia Horticulturae, ,vol. 109, 2006, pp. 238-243.

[21]. Nerson H. Effect of fruit shape and plant density on seed yield and quality of squash. Scientia Horticulturae, vol. 105 (3), 2005, pp. 293-304.

[22]. Maggs-Kölling G., Madsen S. and Christiansen J. A phenetic analysis of morphological variation in Citrullus lanatus in Namibia.Genetic Resources and Crop Evolution, vol. 47, 2000, pp. 385-393.

[23]. Gusmini G. Watermelon (Citrullus lanatus) breeding handbook. In: Raleigh (ed), NC State University, 2003,90 p.

[24]. Ferriol M., Pico B., de Cordova P.F. and Nuez F. Molecular diversity of a germplasm collection of squash (Cucurbitamoschata) determined by SRAP and AFLP markers. Crop Science, vol. 44, 2004, pp. 653-664. 
International Journal of Advances in Scientific Research and Engineering (ijasre), Vol 5 (7), July-2019

[25]. Dey S.S., Singh A.K., Chandel D. \& Behera T.K..Genetic diversity of bitter gourd (Momordica charantia L.) genotypes revealed by RAPD markers and agronomic traits. Scientia Horticulturae, vol. 109, 2006, pp. 21-28.

[26]. Paris H.S. Characterization of Cucurbita pepo collection at the neweya'ar research center, Israël .Plant Genetic Resources Newsletter, vol. 126, 2001, pp. 41-45.

[27]. Doku E.V.and Karikari S.K. The role of ants in pollination and pod production of bambarra groundnut. Economic Botany vol.25, 1971, pp. 357-362.

[28]. Azam-Ali S.N., Sesay A., Karikari S.K., Massawe F.J., Aguilar-Manjarrez J., Bannayan M. \& Hampson K.J. (2001). Assessing the potential of an underutilized crop- a case study using bambara groundnut. Experimental Agriculture 37: pp. 433-472.

[29]. Jarvis D.I., Zoes V., Nares D. and Hodgkin T. On-farm management of crop genetic diversity and the Convention on Biological Diversity program of work on agricultural biodiversity. Plant Genetics Resources Newsletter, vol.138, 2004, pp. 5-17. 